\title{
Preserving Liberty WhILE InCReasing SAFETy: Why INDIANA SHOULD OUTLAW SOBRIETY CHECKPOINTS
}

\author{
JACOB VISSING ${ }^{*}$
}

\section{INTRODUCTION}

In 2011, thirty percent of fatal automobile crashes in the United States involved alcohol-impaired driving. ${ }^{1}$ During that same year in Indiana, 195 out of 675 fatal vehicular crashes involved a drunk driver with a blood-alcohol content of 0.08 or higher. ${ }^{2}$ Based on this data, no one can reasonably argue that drunk driving is not a serious public policy issue nationwide and in the State of Indiana. ${ }^{3}$ Many people across the United States have been personally affected by drunk driving. Mothers Against Drunk Driving describes the impact of drunk driving accurately, stating, "[e]ach crash, each death, each injury impacts not only the person in the crash, but family, friends, classmates, coworkers and more." 4

Lawmaking bodies and law enforcement agencies largely ignored the drunk driving epidemic until the 1980s. ${ }^{5}$ In the early 1980s, with insistence and support from the federal government, state task forces across the country examined drunk driving in order to formulate new laws to fight the problem. ${ }^{6}$ Furthermore, in 1983, the Presidential Commission on Drunk Driving made a series of recommendations to combat drunk driving. ${ }^{7}$ The subsequent changes in law included, among others, blood-alcohol limits, open container prohibitions, and mandatory sentences. ${ }^{8}$

Laws combatting drunk driving are only as effective as their means of enforcement. For years, state and local law enforcement agencies have deployed

* J.D. Candidate, 2015, Indiana University Robert H. McKinney School of Law; B.A., Indiana University, Bloomington, Indiana. I would like to thank my parents, Tim and Amy, my brother, Nick, and my fiancée, Megan, for their love and support over the years.

1. Fatal Crashes and Percent Alcohol-Impaired Driving, by Time of Day and Crash Type, Fatality Analysis Reporting System (FARS) Encyclopedia, NAT'L HighWAY TRAFFIC SAFETY ADMIN., http://www-fars.nhtsa.dot.gov/Crashes/CrashesAlcohol.aspx (last visited Oct. 9, 2013), archived at http://perma.cc/Z24Y-KCJ7 (showing in a graphical chart that 9001 out of 29,757 fatal car crashes in 2011 involved "at least one driver or motorcycle rider [with] a BAC of .08 or higher").

2. Id.

3. Id.

4. Drunk Driving, Mothers Against DrunK DrIVIng (MADD), http://www.madd.org/ drunk-driving/ (last visited Sept. 28, 2013), archived at http://perma.cc/XK2S-XUH6.

5. Gerald D. Robin, Waging the Battle Against Drunk Driving: Issues, COUNTERMEASURES, AND EFFECTIVENESS 7-9 (1991).

6. Id. at 9.

7. Id. at 13 .

8. Id. at 13-14. 
"sobriety checkpoints." Sobriety checkpoints are roadblocks set up by police officers at a specific location where a predetermined proportion of drivers are stopped and questioned. ${ }^{10}$ Checkpoints are mostly deployed on weekends and during holidays, when drunk driving is most common. ${ }^{11}$ If the drivers who are stopped at the checkpoint display no apparent signs of intoxication, they are allowed to continue on their way. ${ }^{12}$ However, if the driver appears intoxicated, police proceed as if it were an ordinary "for cause" police stop. ${ }^{13}$

Despite large public support for sobriety checkpoints, ${ }^{14}$ critics argued the lack of individualized suspicion in sobriety checkpoints constituted a Fourth Amendment violation. ${ }^{15}$ The United States Supreme Court addressed this issue in Michigan Department of State Police v. Sitz, holding that sobriety checkpoints do not violate the Fourth Amendment. ${ }^{16}$ However, the battle did not stop with the United States Supreme Court's holding, as several state supreme courts have since held sobriety checkpoints to be invalid under state constitutions. ${ }^{17}$ Additionally, other states have statutes restricting, and in some cases, banning the use of sobriety checkpoints. ${ }^{18}$

Those who support sobriety checkpoints cite their public support, high visibility, and dual function in catching and deterring drunk drivers. ${ }^{19}$ Alternatively, those opposing sobriety checkpoints criticize their lack of individualized suspicion, low arrest yields, and the availability of less intrusive alternatives. ${ }^{20}$ Nevertheless, a large majority of states follow the framework of the United States Supreme Court, allowing sobriety checkpoints. ${ }^{21}$

Indiana is one of thirty-eight states that permit the use of sobriety checkpoints to combat drunk driving. ${ }^{22}$ In State v. Gerschoffer, the Indiana

9. Id. at 29 .

10. MARgaret C. JASPeR, DRUNK Driving LAW 20 (1999).

11. Id.

12. RoBIN, supra note 5, at 29.

13. Id.

14. JASPER, supra note 10, at 21.

15. RoBIN, supra note 5, at 29-30.

16. Mich. Dep't of State Police v. Sitz, 496 U.S. 444, 451-52 (1990).

17. JASPER, supra note 10, at 20; see, e.g., Sitz v. Dep't of State Police, 506 N.W.2d 209, 225 (Mich. 1993) (holding sobriety checkpoints violated the Michigan Constitution).

18. See, e.g., IOWA CODE $\S 321 \mathrm{~K} .1$ (2013).

19. See JASPER, supra note 10, at 20-21; see generally Sobriety Checkpoints, MOTHERS AGAINST DRUNK DRIVING (MADD), http://www.madd.org/laws/law-overview/Sobriety_ Checkpoints_Overview.pdf (last modified May 2012), archived at http://perma.cc/8J4C-HP54 (describing and advocating the use of sobriety checkpoints).

20. RoBIN, supra note 5, at 39.

21. JASPER, supra note 10, at 20.

22. See Haw. Rev. Stat. § 291E-20 (2013); NeV.Rev. Stat. § 484B.570 (2013); N.H. Rev. StAT. ANN. § 265:1-a (2013); N.C. Gen. STAT. § 20-16.3A (2013); UtAH CodE ANN. § 77-23-103 (West 2013); Ex parte Jackson, 886 So.2d 155 (Ala. 2004); State v. Super. Ct. In and For Pima Cnty., 691 P.2d 1073 (Ariz. 1984); Mullinax v. State, 938 S.W.2d 801 (Ark. 1997); Ingersoll v. 
Supreme Court held that sobriety checkpoints do not violate the Indiana Constitution's prohibition on unreasonable searches and seizures. ${ }^{23}$ Certainly there is a substantial government interest in combatting drunk driving and it is a very emotional issue in Indiana and nationwide. However, best intentions should not be enough to circumvent traditional constitutional privacy protections and limitations on government action without substantial, verifiable justification. Because effective, less intrusive means exist to combat drunk driving, ${ }^{24}$ the Indiana General Assembly should display the caution that the Indiana Supreme Court lacked in Gerschoffer and protect the civil liberties of Hoosiers by banning suspicionless sobriety checkpoints. Banning checkpoints is not purchasing liberty at the expense of safety. ${ }^{25}$ Existing methods of drunk driving patrols, combined with some of the tactics used for sobriety checkpoints, will provide plenty of protection to Hoosier motorists. ${ }^{26}$ By enacting legislation outlawing the use of sobriety checkpoints and outlining alternative tactics, Indiana lawmakers have the opportunity to take a stand for civil liberties, while also taking an equally strong stand against drunk driving.

The purpose of this Note is to analyze the effectiveness of sobriety checkpoints in reducing drunk driving fatalities by comparing drunk driving statistics of states permitting checkpoints to those prohibiting them. Furthermore, this Note will propose a new path forward for Indiana; the new path will seek to protect civil liberty while more effectively combatting the serious

Palmer, 743 P.2d 1299 (Cal. 1987); People v. Rister, 803 P.2d 483 (Colo. 1990); State v. Mikolinski, 775 A.2d 274 (Conn. 2001); Bradley v. State, 858 A.2d 960 (Del. 2004); State v. Jones, 483 So.2d 433 (Fla. 1986); Hardin v. State, 587 S.E.2d 634 (Ga. 2003); People v. Bartley, 486 N.E.2d 880 (Ill. 1985); State v. Gerschoffer, 763 N.E.2d 960 (Ind. 2002); Davis v. Dep't of Revenue, 843 P.2d 260 (Kan. 1992); Commonwealth v. Buchanon, 122 S.W.3d 565 (Ky. 2003); State v. Jackson, 764 So.2d 64 (La. 2000); State v. Leighton, 551 A.2d 116 (Me. 1988); Little v. State, 479 A.2d 903 (Md. 1984); Commonwealth v. Trumble, 483 N.E.2d 1102 (Mass. 1985); Graham v. State, 878 So. 2d 162 (Miss. Ct. App. 2004); State v. Welch, 755 S.W.2d 624 (Mo. Ct. App. 1988); State v. Koncaba, 674 N.W.2d 485 (Neb. Ct. App. 2004); State v. Moskal, 586 A.2d 845 (N.J. Super. Ct. App. Div. 1991); City of Las Cruces v. Betancourt, 735 P.2d 1161 (N.M. Ct. App. 1987); People v. Scott, 473 N.E.2d 1 (N.Y. 1984); City of Bismark v. Uhden, 513 N.W.2d 373 (N.D. 1994); State v. Eggleston, 617 N.E.2d 1325 (Ohio Ct. App. 1996); Geopfert v. State ex rel. Dep't of Pub. Safety, 884 P.2d 1218 (Okla. Crim. App. 1994); Commonwealth v. Tarbert, 535 A.2d 1035 (Pa. 1987); State v. Tilton, 561 N.W.2d 660 (S.D. 1997) (discusses in dicta the constitutionality of sobriety checkpoints); State v. Downey, 945 S.W.2d 102 (Tenn. 1997); State v. Martin, 496 A.2d 442 (Vt. 1985); Lowe v. Commonwealth, 337 S.E.2d 273 (Va. 1985); Carte v. Cline, 460 S.E.2d 48 (W. Va. 1995); see also Sobriety Checkpoint Laws, GOVERNORS HIGHWAY SAFETY ASSOCIATION (Jan. 2015) http://www.ghsa.org/html/stateinfo/laws/checkpoint_laws.html, archived at http://perma.cc/6DCS-PXCK (listing sobriety checkpoint laws by state; South Carolina does not have a statute or court case expressly addressing sobriety checkpoints).

23. Gerschoffer, 763 N.E.2d at 966.

24. See infra Part VI.

25. See infra Part VI.

26. See infra Part VI. 
problem of drunk driving. Part I discusses the United States Supreme Court's decision in Michigan Department of State Police v. Sitz, which upheld sobriety checkpoints under the Fourth Amendment. Part II examines the Indiana Supreme Court's decision in State v. Gerschoffer and how sobriety checkpoints are conducted in Indiana. Part III explores state prohibitions on sobriety checkpoints, specifically those in Michigan, Minnesota, Idaho, Rhode Island, and Iowa. Part IV identifies the potential for abuse of authorized sobriety checkpoints and the risk they pose for civil liberties. Part V analyzes the effectiveness of sobriety checkpoints in reducing drunk driving fatalities. Part VI proposes specific alternatives for Indiana to maximize civil liberty and public safety. Finally, Part VII sets forth a proposed statute for Indiana.

\section{SOBRIETY CHECKPoINTS UnDER THE FoURTH AMENDMENT}

The right of the people to be secure in their persons, houses, papers, and effects, against unreasonable searches and seizures, shall not be violated, and no warrants shall issue, but upon probable cause, supported by oath or affirmation, and particularly describing the place to be searched, and the persons or things to be seized. ${ }^{27}$

Traditionally, alcohol related stops occur when a patrolling police officer observes abnormal driving behavior that gives reasonable suspicion of impaired driving. ${ }^{28}$ Reasonable suspicion is "[a] particularized and objective basis, supported by specific and articulable facts, for suspecting a person of criminal activity." ${ }^{29}$ Officers making discretionary stops must have reasonable suspicion. ${ }^{30}$ The burden placed on law enforcement to meet this standard is fairly low; a vast array of behaviors may be reasonably suspect to the objective observer. $^{31}$

Following a valid police stop, officers must have probable cause, meaning high probability of a suspect's guilt, in order to make an arrest. ${ }^{32}$ Thus, generally, reasonable suspicion is the gateway to the process of enforcing drunk driving laws. ${ }^{33}$ Sobriety checkpoints constitute an exception to the reasonable suspicion standard. ${ }^{34}$

27. U.S. CONST. amend. IV.

28. RoBIN, supra note 5, at 21.

29. BLACK's LAW DiCTIONARY (9th ed. 2009).

30. RoBIN, supra note 5, at 21.

31. Id. at 21-22 (listing several possible indicators of alcohol impairment, including: wide turns; weaving in roadway; straddling center line; speeding; driving slowly; braking erratically; turning abruptly; drifting from lane to lane; signaling inconsistently; slow response time at traffic lights; etc.).

32. $I d$. at 22 .

33. Id. at 21-22.

34. See City of Indianapolis v. Edmond, 531 U.S. 32, 37-38 (2000) (describing suspicionless checkpoint programs that have been upheld by the United States Supreme Court). 
The tidal wave of drunk driving laws in the 1980s brought with it sobriety checkpoints. ${ }^{35}$ Critics argued that the use of police checkpoints to combat drunk driving blatantly violated the Fourth Amendment's ban on unreasonable searches and seizures. ${ }^{36}$ The United States Supreme Court finally settled the issue in 1990 with their decision in Michigan Department of State Police v. Sitz. ${ }^{37}$ Although the Court had spoken on police checkpoints before ${ }^{38}$ and had vaguely suggested in dicta that sobriety checkpoints could be upheld, ${ }^{39}$ Sitz was the first time the Court ruled directly on the constitutionality of sobriety checkpoints. ${ }^{40}$ In Sitz, the Court held that stops at sobriety checkpoints constitute a Fourth Amendment "seizure." ${ }^{41}$ Furthermore, the Court held that stops at sobriety checkpoints are "reasonable" and, therefore, consistent with the Fourth Amendment. ${ }^{42}$

Sitz involved a sobriety checkpoint program established by the Michigan State Police Department. ${ }^{43}$ The police department established guidelines governing the operations, the locations, and the publicity given to the checkpoint program. ${ }^{44}$ The checkpoint yielded just two arrests out of 126 vehicles that passed through, with the average duration of each stop totaling twenty-five seconds. ${ }^{45}$

In reaching its holding, the Court described the significant human toll of drunk driving and balanced it against the relatively brief stops of the Michigan checkpoint program. ${ }^{46}$ Furthermore, the Court distinguished their holding from that in Delaware v. Prouse, where the Court had struck down random stops seeking unlicensed drivers and unsafe vehicles. ${ }^{47}$ In Prouse, the Court reasoned, "the percentage of all drivers on the road who are driving without a license is very small and ... the number of licensed drivers who will be stopped in order to find one unlicensed operator will be large indeed." ${ }^{48}$ It seems that a checkpoint program yielding arrests in less than two percent of stops would fail under the same logic. However, the Sitz Court looked to its holding in MartinezFuerte, where checkpoints established to detect illegal aliens were held

35. See RoBIN, supra note 5, at 29.

36. Id. at 40 .

37. See Mich. Dep't of State Police v. Sitz, 496 U.S. 444, 455 (1990); see also JASPER, supra note 10, at 20; RoBIN, supra note 5, at 40 .

38. See, e.g., United States v. Martinez-Fuerte, 428 U.S. 543 (1976) (holding warrantless checkpoints for detecting illegal aliens are consistent with the Fourth Amendment).

39. See Delaware v. Prouse, 440 U.S. 648, 663 (1979) ("Questioning of all oncoming traffic at roadblock-type stops is one possible alternative.").

40. RoBIN, supra note 5, at 40-42.

41. Sitz, 496 U.S. at 450 (citing Martinez-Fuerte, 428 U.S. at 556).

42. Id. at 455 .

43. Id. at 447 .

44. Id.

45. Id. at 448 .

46. Id. at 451 .

47. Id. at 454 (citing Delaware v. Prouse, 440 U.S. 648, 659-60 (1979)).

48. Prouse, 440 U.S. at 659-60. 
reasonable despite a detection rate of only $0.12 \% .{ }^{49}$ Thus, the Court found a drunk driving arrest rate of roughly one percent sufficiently effective to justify sobriety checkpoints. ${ }^{50}$ The Court in Sitz concluded, "the balance of the State's interest in preventing drunk driving, the extent to which this system can reasonably be said to advance that interest, and the degree of intrusion upon individual motorists who are briefly stopped, weighs in favor of the state program." 51

The Court's analysis received criticism from a variety of angles. Critics of this holding argue that the reasonableness test was improperly applied. ${ }^{52}$ In his dissent, Justice Stevens argued, "The Court overvalues the law enforcement interest in using sobriety checkpoints, undervalues the citizen's interest in freedom from random, unannounced investigatory seizures, and mistakenly assumes that there is 'virtually no difference' between a routine stop at a permanent, fixed checkpoint and a surprise stop at a sobriety checkpoint." $53 \mathrm{He}$ further noted that "the record in this case makes clear that a decision holding these suspicionless seizures unconstitutional would not impede the law enforcement communities remarkable progress in reducing the death toll on our highways." ${ }^{4}$

The Sitz holding relied heavily on the Court's holding in Martinez-Fuerte; however, the police checkpoints at issue in each case are distinguishable. ${ }^{55}$ Unlike in drunk driving cases, where police may easily detect obvious indicators of impaired driving, ${ }^{56}$ vehicles carrying illegal aliens convey no readily apparent characteristics. ${ }^{57}$ Furthermore, there is a greater immediate danger posed to the public by drunk drivers than by vehicles carrying illegal aliens. Although this seems to make a strong case for sobriety checkpoints, that is not necessarily the case. Alternative, less intrusive methods exist, which are highly effective in removing impaired drivers from the nation's roadways. ${ }^{58}$ By contrast, given the length of the United States' border, without checkpoints law enforcement officers have few if any realistic opportunities to apprehend illegal aliens as they enter the United States. ${ }^{59}$

49. Sitz, 496 U.S. at 455 (citing United States v. Martinez-Fuerte, 428 U.S. 543, 554 (1976)).

50. Id. at 455 .

51. Id.

52. See, e.g., Michael F. Lotito, Unsteady on its Feet: Sobriety Checkpoint Reasonableness, 67 WASH. \& LEE L. REV. 735, 784-85 (2010) (advocating the use of economic theory in determining sobriety checkpoint reasonableness under the Fourth Amendment).

53. Sitz, 496 U.S. at 462-63 (Stevens, J., dissenting).

54. Id. at 460 .

55. Id. at 450-53.

56. RobIN, supra note 5, at 21; see also Sitz, 496 U.S. at 458 (Stevens, J., dissenting).

57. See Sitz, 496 U.S. at 458 (Stevens, J., dissenting).

58. See generally Sobriety Checkpoints, supra note 19 (describing roving patrols and saturation patrols in addition to sobriety checkpoints).

59. See United States v. Martinez-Fuerte, 428 U.S. 543, 556 (1976); see also City of Indianapolis v. Edmond, 531 U.S. 32, 38-39 (2000). 
Sobriety checkpoints are comparable to truck weigh-stations, considering the public safety concerns. ${ }^{60}$ However, there are characteristics that distinguish weigh-stations from sobriety checkpoints. Inspection checkpoints for trucks are more narrowly applied, targeting large commercial trucks. Sobriety checkpoints target all, or a predetermined number of motorists on a particular road at a particular time. ${ }^{61}$ Additionally, trucks carrying too much weight may not be readily apparent to law enforcement officials, unlike the many apparent signs of impaired driving. ${ }^{62}$

\section{SOBRIETY CHECKPOINTS IN INDIANA}

In State v. Gerschoffer, the Indiana Supreme Court held that sobriety checkpoints were not per se violations of the state's constitutional prohibition of unreasonable searches and seizures. ${ }^{63}$ The holding in Gerschoffer placed Indiana within the clear majority of jurisdictions that permit sobriety checkpoints as an accepted method of combatting drunk driving. ${ }^{64}$

\section{A. State v. Gerschoffer: Reasonableness Factors}

According to the Indiana Supreme Court, the "reasonableness" of sobriety checkpoints under the Indiana Constitution depends on the following six factors: (1) a neutral plan approved by appropriate officials; (2) an objective location and timing; (3) the amount of police discretion; (4) the degree of intrusion; (5) safe conditions; and (6) effectiveness. ${ }^{65}$ This Indiana factor test for checkpoint reasonableness is derived from factors considered by courts in other states. ${ }^{66}$ This factors test for reasonableness is more stringent than the balancing test used by the United States Supreme Court in Sitz. ${ }^{67}$

1. Neutral Plan Approved by Appropriate Officials.-The court in Gerschoffer reasoned that "formal guidelines adopted at an appropriate policymaking level" for conducting sobriety checkpoints support their reasonableness. ${ }^{68}$ Essentially, in the courts view, a neutral plan approved by law enforcement

60. See generally Sitz, 496 U.S. at 454 (discussing the propriety of roadside weigh-stations and safety checkpoints under the Court's holding in Prouse).

61. JASPER, supra note 10, at 20.

62. RoBIN, supra note 5, at 21.

63. State v. Gerschoffer, 763 N.E.2d 960, 966 (Ind. 2002).

64. Sobriety Checkpoint Laws, supra note 19 (listing sobriety checkpoint laws by state).

65. Gerschoffer, 763 N.E.2d at 967-71.

66. Id. at 967 (citations omitted).

67. See id. at 967-71 (describing the factors test to determine sobriety checkpoint reasonableness); Mich. Dep't of State Police v. Sitz, 496 U.S. 444, 455 (1990) (describing the results of the Court's balancing test).

68. Gerschoffer, 763 N.E.2d at 967 (citing State v. Boisvert, 671 A.2d 834, 837 (Conn. App. Ct. 1996)) (discussing a Connecticut court's approval the state public safety commissioner's guidelines which included "advanced approval by ranking officers" and "advance publicity," among other requirements). 
officials who may be held accountable, strikes in favor of reasonableness; however, the plan's reasonableness depends on a case-by-case assessment of its effectiveness. ${ }^{69}$

2. Objective Location and Timing.- "A seizure is not reasonable unless it is well calculated to effectuate its purpose."70 Checkpoints should narrowly target impaired drivers; generalized police dragnets established to "make sure everybody is doing what they're supposed to" are not permissible under the Indiana Constitution. ${ }^{71}$ Public notice of the checkpoint should also indicate the specific objective in order to adequately inform the public of the narrow scope of intrusion they are likely to encounter. ${ }^{72}$

According to the court, when choosing a location, law enforcement officials should look for a site with a high incidence of drunk driving. ${ }^{73}$ Furthermore, officers should choose a time of day that is most likely to result in drunk driving arrests. ${ }^{74}$ In sum, "[t]o be constitutionally reasonable, the location and timing of sobriety checkpoints should take into account police officer safety, public safety, and public convenience." $" 75$

3. Police Discretion. - The court in Gerschoffer agreed with many other state courts when it concluded that the level of police discretion used during sobriety checkpoints is one of the most important factors in determining reasonableness. ${ }^{76}$ Police discretion, in the court's view, must be limited to "ensure against arbitrary or inconsistent actions by screening officers." 77 The neutral sobriety checkpoint plan, described above, should provide specific guidelines to law enforcement officials regarding their treatment of motorists. ${ }^{78}$

4. Degree of Intrusion. - The degree of intrusion depends on the duration of stops where no violation was detected and the ease of checkpoint avoidance. ${ }^{79}$ "The more avoidable a roadblock is, the less it interferes with the liberty of the individual drivers. A roadblock need hardly be altogether voluntary, however, or it would have little enforcement or deterrent value." ${ }^{80}$

5. Safe Conditions. - The court touched briefly on this factor. ${ }^{81}$ It concluded that the location of the checkpoint at issue in this case, in a well-lit area adjacent to a parking lot where the cars could pull off the road, struck in favor of the

69. Id.

70. Id. (quoting State v. Garcia, 500 N.E.2d 158, 167 (Ind. 1986) (Shepard, J., dissenting)).

71. Id. at 967-68 (citations omitted).

72. See generally id.

73. Id. at 968 .

74. Id.

75. Id.

76. Id. at 968-69.

77. Id. at 969 .

78. Id.

79. Id.

80. Id.

81. See id. at 970. 
checkpoint's reasonableness. ${ }^{82}$

6. Effectiveness. - In order to determine the effectiveness of sobriety checkpoints, the court considered apprehension rates and, more importantly, the deterrent effect of publicized checkpoints. ${ }^{83}$ Here, the court concluded that evidence of a "media blitz" was needed to overcome a low arrest rate; without such publicity, the court could not infer that the low arrest rate was the result of the deterrent effect of the checkpoint. ${ }^{84}$

\section{B. Gerschoffer: Takeaway}

Although the Indiana Supreme Court held that sobriety checkpoints are not per se violations of the Indiana Constitution, ${ }^{85}$ the court concluded that the checkpoint at issue in Gerschoffer did violate the state constitution. ${ }^{86}$ The court reasoned,

In light of the above factors, with particular emphasis on the high level of officer discretion and the very weak link between the public danger posed by [operating while intoxicated] and the objective, location and timing of the checkpoint, the State did not meet its burden to show that this roadblock was constitutionally reasonable $\ldots{ }^{87}$

The stricter standard applied by the Indiana Supreme Court ${ }^{88}$ is commendable; however, as this Note will later demonstrate, it is still ripe for abuse.

\section{State PROHibitions AND Limitations ON SOBRIETy CHECKPoINTS}

Twelve states currently prohibit sobriety checkpoints by interpretation of their state constitution, state statutes, and state court interpretations of the United States Constitution. ${ }^{89}$ This Note examines the respective state court rulings in

82. Id.

83. Id.

84. Id. at $970-71$.

85. Id. at 966 .

86. Id. at 971 .

87. Id.

88. See id. at 967-71 (describing the factors test to determine sobriety checkpoint reasonableness); Mich. Dep't of State Police v. Sitz, 496 U.S. 444, 455 (1990) (describing the results of the Court's balancing test).

89. See IOWA CODE $§ 321 \mathrm{k} .1$ (2013) (statute listing permissible reasons for investigative checkpoints); State v. Henderson, 756 P.2d 1057 (Idaho 1988); Sitz v. Dep't of State Police, 506 N.W.2d 209, 210 (Mich. 1993) (involving the same checkpoint at issue in Sitz, 496 U.S. at 444); Ascher v. Comm'r Pub. Safety, 519 N.W.2d 183 (Minn. 1994); Nelson v. Lane Cnty., 743 P.2d 692 (Or. 1987); Pimental v. Dep't of Transp., 561 A.2d 1348 (R.I. 1989); Holt v. State, 887 S.W.2d 16 (Tex. Crim. App. 1994); City of Seattle v. Mesiani, 755 P.2d 775 (Wash. 1988); Wis. STAT. § 968.24 (2013) (statute requiring reasonable suspicion for temporary police questioning); Brown v. State, 944 P.2d 1168 at 1171 (Wyo. 1997) (citations omitted) (explaining that investigatory stops require "the presence of specific and articulable facts and rational inferences which give rise to a 
Michigan, Minnesota, Idaho, and Rhode Island, which prohibit sobriety checkpoints under their state constitutions. This Note also discusses the statutory limitations in New Hampshire and Iowa.

\section{A. Prohibitions Under State Constitutions}

1. Michigan.-Interestingly, the same sobriety checkpoint program that was upheld under the Fourth Amendment by the United States Supreme Court in Sitz,${ }^{90}$ was subsequently struck down by the Michigan Supreme Court under the Michigan Constitution. ${ }^{91}$ In Sitz, the Michigan Supreme Court found "no support in the constitutional history of Michigan for the proposition that the police may engage in warrantless and suspicionless seizures of automobiles for the purpose of enforcing the criminal law." 92

Michigan's history of Prohibition Era alcohol smuggling operations from Canada resulted in significant precedent in the area of automobile seizures for alcohol related crimes. ${ }^{93}$ The court's core reason for concluding that sobriety checkpoints violate the Michigan Constitution was the high level of protection from criminal seizures that state law had historically given to citizens. ${ }^{94}$ According to the Michigan Supreme Court,

$[T]$ he history of our jurisprudence conclusively demonstrates that, in the context of automobile seizures, we have extended more expansive protection to our citizens than that extended in Sitz. This [c]ourt has never recognized the right of the state, without any level of suspicion whatsoever, to detain members of the population at large for criminal investigatory purposes. Nor has Michigan completely acquiesced to the judgment of "politically accountable officials" when determining reasonableness in such a context. ${ }^{95}$

Because of this distinction drawn from the United States Supreme Court's holding in Sitz, the Michigan Supreme Court embraced the "New Federalism" movement, ${ }^{96}$ adopting broader protections than those afforded under federal law. ${ }^{97}$

2. Minnesota.-The year after Michigan ruled sobriety checkpoints

reasonable suspicion that a person has committed or may be committing a crime."). Sobriety Checkpoints, supra note 19 (Alaska and Montana have not expressly ruled on sobriety checkpoints, but choose not to conduct them).

90. Sitz, 496 U.S. at 455.

91. Sitz, 506 N.W.2d at 210.

92. Id.

93. See id. at 218-19; see, e.g., People v. Roache, 211 N.W. 742 (Mich. 1927) (discussing suspicionless stops of automobiles).

94. Sitz, 506 N.W.2d at 224-25.

95. Id. at 223-24 (citations omitted).

96. See generally id. at 212-13 (discussing the "New Federalism" movement).

97. Id. at 224. 
unconstitutional, another Midwest state, Minnesota, also prohibited the practice. ${ }^{98}$ In Ascher v. Commissioner of Public Safety, the Minnesota Supreme Court held that sobriety checkpoints violate article I, section 10 of the Minnesota Constitution. ${ }^{99}$ The ruling was based on the "state's failure to meet its burden of articulating a persuasive reason for dispensing with the individualized suspicion requirement in this context." ${ }^{100}$ According to the court, to depart from the general individualized suspicion requirement, the state must demonstrate that:

[I]t is impractical to require the police to develop individualized suspicion and that a departure from the individualized suspicion requirement will significantly help police achieve a higher arrest rate than they can achieve using more conventional means of apprehending alcohol-impaired drivers and (b) that this outweighs the interests of ordinary citizens in not having their privacy or their freedom of movement interfered with by police investigators who do not have any reason to suspect them of wrongdoing. ${ }^{101}$

Furthermore, the court criticized the application of the balancing test in Sitz, citing Justice Stevens' dissent, in which he "pointed to the state's failure to establish that a higher arrest rate could not be achieved by following the requirement of individualized suspicion." ${ }^{102}$ Unlike the Court in Sitz, ${ }^{103}$ the court in Ascher was underwhelmed by the $1.4 \%$ arrest rate, ${ }^{104}$ and ultimately held this sobriety checkpoint to be unconstitutional. ${ }^{105}$

3. Idaho.-In State v. Henderson, the Idaho Supreme Court held that sobriety checkpoints violate the state constitution's prohibition of unreasonable searches and seizures. ${ }^{106}$ According to the court, there are three types of encounters between citizens and law enforcement officers: (1) the arrest, which requires probable cause; (2) the investigative stop, supported by individualized suspicion, which is an exception to constitutional protections; and (3) the voluntary encounter, which is not a seizure at all and falls outside the scope of constitutional protection. ${ }^{107}$ This framework suggested to the court that law enforcement officers generally need "individualized suspicion of criminal wrongdoing prior to stopping the driver of an automobile." 108 It is important to note that this analysis occurred prior to the United States Supreme Court's ruling

98. Ascher v. Comm'r Pub. Safety, 519 N.W.2d 183, 187 (Minn. 1994).

99. Id.; see generally MINN. CONST. art. I, § 10.

100. Ascher, 519 N.W.2d at 187.

101. Id. at 186.

102. Id. at 185.

103. See Mich. Dep’t of State Police v. Sitz, 496 U.S. 444, 455 (1990) (“'A]pproximately 1.6 $\%$ of drivers passing through the checkpoint were arrested for alcohol impairment.").

104. See Ascher, 519 N.W.2d at 184.

105. Id. at 187.

106. State v. Henderson, 756 P.2d 1057 (Idaho 1988).

107. Id. at 1059 (citing State v. Zapp 701 P.2d 671, 674-75 (Idaho Ct. App. 1985)).

108. Id. (citations omitted). 
in Sitz; however, the court's decision in Henderson was based solely on the Idaho Constitution rather than federal precedent. ${ }^{109}$

Additionally, the court in Henderson discussed the fatality toll of drunk driving and the state's significant interest in stopping it. ${ }^{110}$ However, it determined that warrantless roadblocks are no more efficient in achieving that goal than usual procedures. ${ }^{111}$ Accordingly, the court held, "where police lack express legislative authority, particularized suspicion of criminal wrongdoing and prior judicial approval, roadblocks established to apprehend drunk drivers cannot withstand constitutional scrutiny."112

4. Rhode Island.-In Pimental v. Department of Transportation, the Rhode Island Supreme Court held that "roadblocks or checkpoints, established to apprehend persons violating the law against driving under the influence of intoxicating beverages or drugs, operate without probable cause or reasonable suspicion and violate the Rhode Island Constitution." 113 The holding was largely based on the low arrest rates associated with sobriety checkpoints. ${ }^{114}$ Furthermore, the court did not believe the deterrent effect of checkpoint programs justified their use. ${ }^{115}$ The court stated, "[t]he effectiveness of such deterrence may be highly questionable... Even assuming that roadblocks may have some deterrent effect, we believe that it is purchased at too high a price."116

Although the Rhode Island Supreme Court acknowledged the compelling state interest in combatting drunk driving, the court also recognized that there are less intrusive ways to address drunk driving. ${ }^{17}$ In the court's view, law enforcement officials observing traffic may only "apprehend drunk drivers on the basis of probable cause or at least individualized articulable suspicion." 118

\section{B. Statutory Limitations}

1. New Hampshire.-New Hampshire allows the use of sobriety checkpoints to combat drunk driving; however, the legislature enacted a statute requiring law enforcement officials to first obtain a judicial warrant. ${ }^{119}$ The statute titled "Sobriety Checkpoints" reads as follows:

Notwithstanding any provision of law to the contrary, no law enforcement officer or agency shall establish or conduct sobriety

109. Id. at 1063 .

110. Id. at 1061 .

111. Id.

112. Id. at 1063 .

113. Pimental v. Dep't of Transp., 561 A.2d 1348, 1352 (R.I. 1989).

114. Id.

115. Id.

116. $I d$.

117. $I d$.

118. Id.

119. See N.H. Rev. StAT. ANN. § 265:1-a (2013). 
checkpoints for the purposes of enforcing criminal laws of this state, unless such law enforcement officer or agency petitions the superior court and the court issues an order authorizing the sobriety checkpoint after determining that the sobriety checkpoint is warranted and the proposed method of stopping vehicles satisfies constitutional guarantees. ${ }^{120}$

In New Hampshire, the constitutionality of sobriety checkpoints depends on "(1) whether it is more effective at advancing the public interest than other, less intrusive means; and (2) whether its value outweighs the degree of intrusion it involves." 121 Similar to other states that have upheld the constitutionality of sobriety checkpoints, the New Hampshire Supreme court reasoned that publicity allows checkpoints to overcome low arrest yields because the combination of the two provide a reasonable inference that checkpoints have deterred drunk driving. ${ }^{122}$

The warrant requirement is similar to outright constitutional approval of sobriety checkpoints because, in the end, the permissibility of the checkpoint rests with the judiciary. Although the warrant requirement necessitates judicial approval of the program prior to its implementation, its approval rests in the hands of a trial court judge. Trial court judges may be more susceptible to the pressures of local voters, suggesting a high likelihood of approval due to the general popularity of sobriety checkpoints. ${ }^{123}$ However, the only way a judge will be forced to weigh the constitutionality of a checkpoint in jurisdictions with outright approval is if an aggrieved party challenges the admission of evidence related to the stop or sues the police department outright. The costs of this process may be high in comparison to the costs imposed by a Driving Under the Influence ("DUI") conviction. Moreover, given the national popularity of sobriety checkpoints and the social stigma of drunk driving, someone arrested for driving under the influence of alcohol will not easily garner public sympathy.

2. Iowa.- The Iowa State Legislature enacted a statute pertaining to roadblocks conducted by law enforcement agencies. ${ }^{124}$ The statute authorizes "emergency vehicle roadblocks in response to immediate threats to health, safety, and welfare of the public." 125 Furthermore, the statute authorizes routine roadblocks to enforce compliance with motor vehicle licenses, vehicle registration, and safety equipment. ${ }^{126}$ Sobriety checkpoints are not specifically included in the text of the statute. ${ }^{127}$

120. $I d$.

121. State v. Hunt, 924 A.2d 424, 428 (N.H. 2007) (citing State v. Koppel, 499 A.2d 977, 981 (N.H. 1985)).

122. Id. at 432-34.

123. See JASPER, supra note 10, at 21 (citations omitted).

124. IOWA CODE $\S 321 \mathrm{~K} .1$ (2013).

125. Id.

126. Id.

127. See id. 
In State v. Day, the Iowa Supreme Court determined that a DUI arrest at a police checkpoint established to check for safety equipment, drivers licenses, and vehicle registrations was incidental to the primary goal, and thus did not violate the state statute. ${ }^{128}$ The court concluded that law enforcement officials conducting such a checkpoint "would be derelict in their duties" if they ignored other crimes uncovered by an otherwise lawful checkpoint program. ${ }^{129}$

\section{OPENING THE DOOR FOR ABUSE}

In City of Indianapolis v. Edmond, the United States Supreme Court held that a drug checkpoint program was "indistinguishable from the general interest in crime control," thus it violated the Fourth Amendment. ${ }^{130}$ The Court distinguished the narcotics checkpoint from border patrol checkpoints and sobriety checkpoints, which have both been constitutionally upheld. ${ }^{131}$ According to the Court, "a checkpoint program whose primary purpose [is] to detect ordinary criminal wrongdoing" exceeds the boundaries of the Fourth Amendment. ${ }^{132}$

In dicta, reaffirming previously recognized exceptions to the reasonable suspicion standard for police stops, the Court in Edmond concluded that border checkpoints are necessary due to the uniquely difficult task of protecting the entire United States border. ${ }^{133}$ Furthermore, sobriety checkpoints combat an immediate danger, removing alcohol-impaired drivers from the roads. ${ }^{134}$ Although the Court in Prouse struck down a program that stopped drivers to check their operating licenses and vehicle registrations, the majority in Edmond suggested that a similar program with less officer discretion would be permissible. ${ }^{135}$ The Court in Edmond reasoned that "the common thread of highway safety" runs through the checkpoints described above, making them reasonable under the Fourth Amendment, while checkpoints for general crime control fall short. ${ }^{136}$

As the Iowa Supreme Court's decision in State v. Day demonstrated, ${ }^{137}$ constitutionally permissible checkpoints allow law enforcement to apprehend individuals for an array of crimes many of which do not provide a constitutional basis for their own checkpoints. Even in Indiana, where relatively strict

128. State v. Day, 528 N.W.2d 100, 103 (Iowa 1995).

129. Id.

130. City of Indianapolis v. Edmond, 531 U.S. 32, 48 (2000).

131. Id. at 37-38 (citing Mich. Dep't of State Police v. Sitz, 496 U.S. 444, 455 (1990); United States v. Martinez-Fuerte, 428 U.S. 543, 566-67 (1976)).

132. Id.

133. Id. at 39 .

134. Id.

135. Id.

136. Id. at 40 .

137. See State v. Day, 528 N.W.2d 100, 103 (Iowa 1995). 
constitutional guidelines must be met in order to conduct sobriety checkpoints, ${ }^{138}$ police are prepared to apprehend individuals engaged in any criminal activity that happen to pass through the checkpoint. ${ }^{139}$ For example, in March 2011, the Indiana State Police conducted a large-scale checkpoint program in central Indiana that spanned seven counties. ${ }^{40}$ The operation yielded twenty-three misdemeanor driving while intoxicated ("DWI") arrests, two felony arrests, and seventeen other alcohol-related arrests. ${ }^{141}$ During the same sobriety checkpoint operation, thirty-four non-alcohol-related arrests were made. ${ }^{142}$

Although the Court in Edmond held that checkpoints conducted for the primary purpose of narcotic detection are unconstitutional, the Court stated in dicta that the use of drug sniffing dogs at a lawful automobile seizure did not transform the stop into a search. ${ }^{143}$ In Myers v. State, the Indiana Supreme Court held that a canine sniff test performed on the exterior of a vehicle at a lawful police stop was constitutional. ${ }^{144}$ Thus, it appears that if a sobriety checkpoint meets the criteria set forth in Gerschoffer, ${ }^{145}$ the presence of drug dogs would be permissible.

Additionally, non-alcohol-related arrests are a convenient windfall for law enforcement, and they open the door for potential checkpoint abuse. Once a law enforcement agency satisfies six factors described in Gerschoffer, ${ }^{146}$ they have a green light for a de facto police dragnet. Although individuals who engage in criminal behavior are not sympathetic figures, the personal privacy of the public at-large should not be diminished in order to apprehend law-breakers.

Additionally, new police technology and investigative methods have raised privacy concerns. ${ }^{147}$ Coupling these new forensic tools with police checkpoints

138. See State v. Gerschoffer, 763 N.E.2d 960, 967-971 (Ind. 2002) (describing the factors test to determine sobriety checkpoint reasonableness).

139. See generally Day, 528 N.W.2d at 103 (discussing the duty of police officers at sobriety checkpoints to apprehend any additional criminal wrongdoers); see also Brooks Holland, The Road 'Round Edmond: Steering Through Primary Purposes and Crime Control Agendas, 111 PENN ST. L. REV.293, 302 (2006) (discussing the reasonableness of crime control as a secondary purpose for lawful checkpoint programs).

140. Sobriety Checkpoints Net Impaired Drivers, WTHR (Mar. 18, 2011, 10:03 PM), http://www.wthr.com/story/14277039/sobriety-checkpoints-net-impaired-drivers, archived at http://perma.cc/XBL7-5XV5.

141. Id.

142. Id.

143. City of Indianapolis v. Edmond, 531 U.S. 32, 40 (2000) (citing United States v. Place, 462 U.S. 696, 707 (1983)).

144. Myers v. State, 839 N.E.2d 1146, 1150 (Ind. 2005).

145. See State v. Gerschoffer, 763 N.E.2d 960, $967-71$ (Ind. 2002).

146. See id.

147. See generally Bob Sullivan, Gadget Gives Cops Quick Access to Cell Phone Data, NBC News.COM, (Apr. 20, 2011, 4:09 PM), http://www.nbcnews.com/technology/gadget-gives-copsquick-access-cell-phone-data-6C10406777, archived at http://perma.cc/K842-U4YD (discussing the use of cell phone data extraction devices by Michigan police). 
is a dangerous step towards a police-state dynamic that is in direct conflict with Fourth Amendment principles. ${ }^{148}$ Specifically, new cell phone data extraction devices give law enforcement officials the ability to rip personal information from the cellular devices of suspects without their consent or knowledge. ${ }^{149}$ The American Civil Liberties Union ("ACLU") has been outspoken in its criticism of police using such devices. ${ }^{150}$ Placed in the context of sobriety checkpoints, devoid of individualized suspicion, the community at-large is subjected to this intrusion, not just suspected criminal wrongdoers.

In 2013, the Indiana State Police acquired cell phone data extraction devises, known as "Stingrays." 151 A Stingray device operates like a cell phone tower, allowing officers to track peoples' movements, extract call history and extract text messages from cell phones within its range. ${ }^{152}$ Often, local police departments purchase Stingray devices with federal grant money as a part of a national goal aimed at preventing terrorist attacks in American cities. ${ }^{153}$ According to the Indianapolis Department of Public Safety, as of December 2013, police only used the Stingray device when it had been authorized by a court order. ${ }^{154}$ Generally, a simple court order requires a much lesser burden than what is required for a search warrant, which makes this technology even more frightening to civil libertarians. ${ }^{155}$

The United States Supreme Court's 2014 decision in Riley v. California might have calmed some of these fears. ${ }^{156}$ In Riley, the Court established that a warrant is "generally required" before the search of a cell phone. ${ }^{157}$ However, the Court did recognize that exigent circumstances might require law enforcement officers to search a cell phone data without a warrant, such as bomb threats or circumstances of child abduction. ${ }^{158}$

Imagine the potential privacy intrusion if the Stingray device was deployed during a checkpoint operation. The personal communications and data from

148. Id.

149. Id.

150. See id.

151. Ryan Sabalow, Indiana State Police Tracking Cellphones-but Won't Say How or Why, INDIANAPOLIS STAR (Dec. 9, 2013), http://www.indystar.com/story/news/2013/12/08/indiana-statepolice-tracking-cellphones-but-wont-say-how-or-why/3908333/, archived at $\mathrm{http}: / /$ perma.cc/32YZUC5V.

152. $I d$.

153. Id.; see also John Kelly, Cellphone Data Spying: It's Not Just the NSA, USA TODAY (Dec. 8, 2013), http://www.usatoday.com/story/news/nation/2013/12/08/cellpho.ne-data-spyingnsa-police/3902809/, archived at http://perma.cc/9JHJ-P8HB.

154. Sabalow, supra note 151.

155. Id.

156. See generally Riley v. California, 134 S. Ct. 2473 (2014) (holding that the interest in protecting officer safety nor the interest in preventing the destruction of evidence justified dispensing with the warrant requirement for searches of cell phone data).

157. Id. at 2493.

158. Id. at 2494. 
hundreds of innocent motorists would be vulnerable to spying by law enforcement officials under the guise of public safety. Although Riley will likely prevent regular usage of these tools in conjunction with checkpoints, it does not foreclose on the possibility altogether. ${ }^{159}$ Given that sobriety checkpoints are often used around holidays and major events when the perceived terror risk is also higher, it is not difficult to envision a scenario where these law enforcement tools are used together. ${ }^{160}$

The idea of such technology being used in the connection with police checkpoints serves as an example of the potential danger for unwarranted privacy invasion. Additionally, cell phone data surveillance, and the controversy surrounding its use, serve as an analogue to police checkpoints. Law enforcement procedures and initiatives frequently conflict with the civil liberties. ${ }^{161}$ In 2014, Indiana Governor Mike Pence signed a law requiring a law enforcement to obtain a warrant for data collection and surveillance by cell phone and other devices; however, similar to the Riley decision, there are exceptions for exigent circumstances. ${ }^{162}$ In contrast to public distaste for technological privacy violations, large public support for sobriety checkpoints prevents politicians from challenging their use, thus keeping the intrusive tactic alive. ${ }^{163}$

\section{EFFECTIVENESS OF SOBRIETY CHECKPOINTS IN REDUCING DRUNK DRIVING FATALITIES}

The effectiveness of sobriety checkpoints is unclear and is a subject of disagreement in the courts. Choosing the proper statistic to weigh the effectiveness of checkpoints is difficult; arrest rates and alcohol-related fatality rates are often the numbers used. ${ }^{164}$ Courts have even looked at the lack of

159. Id.

160. See JASPER, supra note 10, at 20; see also Riley, 134 S. Ct. at 2494.

161. See generally Radley Balko, Drunk Driving Laws Are Out of Control, CATO Inst. (July 27, 2004), http://www.cato.org/publications/commentary/drunk-driving-laws-are-out-control, archived at http://perma.cc/W7P4-KXL9 (criticizing law enforcement tactics targeting drunk drivers at the expense of civil liberties); More Disclosures About Stop and Frisk, N.Y. TIMES (Dec. 9, 2013), http://www.nytimes.com/2013/11/30/opinion/more-disclosures-about-stop-andfrisk.html?ref=stopandfrisk\&_r=0, archived at $\mathrm{http} / / /$ perma.cc/57JX-X9SU (criticizing New York City's "stop and frisk" police tactic).

162. Tony Cook, Pence Signs Bill Limited Electronic Surveillance by Police, INDY STAR (Mar. 27, 2014), http://www.indystar.com/story/news/politics/2014/03/27/pence-signs-bill-limitingelectronic-surveillance-police/6978209/.

163. See JASPER, supra note 10, at 21 (citations omitted) ("[T]wo-thirds of the driving age public believe sobriety checkpoints should be used more frequently than they are now.").

164. See Mich. Dep't of State Police v. Sitz, 496 U.S. 444, 454-55 (1990); Jeffrey W. Greene, Battling DUI: A Comparative Analysis of Checkpoints and Saturation Patrols, 72 FBI No, 1, 3-4 LAW ENFORCEMENT BULLETIN (Jan. 2003), available at http://leb.fbi.gov/2003-pdfs/leb-january2003. 
arrests in conjunction with public notice of checkpoints as a sign that they are deterring people from drinking and driving altogether. ${ }^{165}$ Because the primary purpose of DUI enforcement is to prevent senseless deaths on this nation's roads, this section examines drunk driving fatality statistics. Additionally, this section discusses the rationale courts have applied in assessing whether sobriety checkpoints are effective.

\section{A. States Allowing Checkpoints Versus States Prohibiting Checkpoints}

Between 1994 and 2011, thirty-one percent of fatal automobile accidents in the United States involved a driver with a blood-alcohol content of .08 or higher. ${ }^{166}$ During that same timeframe, states that allowed sobriety checkpoints experienced a drunk-driving fatality rate of thirty percent, slightly lower than the national average. ${ }^{167}$ Conversely, states that prohibited the use of sobriety checkpoints had a drunk driving fatality rate of thirty-five percent. ${ }^{168}$

Strictly comparing the numbers between states that allowed sobriety checkpoints and those that disallowed the tactic, one might conclude that this proves checkpoints are effective at removing drunk drivers from the roadways and reducing fatalities. Such analysis is simply lazy and ignores the many variables that play into these statistics. Many factors, such as population density and the frequency and intensity of DUI enforcement, among other factors, skew these numbers and make it difficult to accurately assess the actual impact of sobriety checkpoints. Furthermore, the statistics used to come up with these figures include "alcohol-related" crashes, meaning an accident in which alcohol was involved in any capacity, even if an intoxicated driver was not the cause of the accident. ${ }^{169}$

As discussed above, the Court in Sitz relied heavily on precedent from Martinez-Fuerte when it weighed the effectiveness of the Michigan State Police's sobriety checkpoint program that featured an arrest rate of less than two percent. ${ }^{170}$ In Sitz, an illegal alien checkpoint program had a detection rate of $0.12 \%$, which the Court found was sufficiently effective to sustain its constitutionality. ${ }^{171}$ It is unlikely that such unimpressive arrest rates, in conjunction with any attributable deterrent effect, is the sole cause for the discrepancy in drunk driving fatalities between states allowing and those

165. See State v. Gerschoffer, 763 N.E.2d 960, 970 (Ind. 2002).

166. See Persons Killed, by Highest Driver Blood Alcohol Concentration (BAC) in the Crash, 1994-2011, Fatality Analysis Reporting System (FARS) Encyclopedia, NAT'L HigHWAY TrAFFIC SAFETY ADMIN., http://www-fars.nhtsa.dot.gov/Trends/TrendsAlcohol.aspx (last visited Jan. 19, 2014), archived at http://perma.cc/NZK8-MRZ3 [hereinafter NAT'L HIGHWAY TRAFFIC SAFETY ADMIN.].

167. See id.

168. Id.

169. Balko, supra note 161.

170. Mich. Dep't of State Police v. Sitz, 496 U.S. 444, 455 (1990).

171. Id. (citations omitted). 
disallowing sobriety checkpoints.

In the mid-1990s, Tennessee law enforcement, in partnership with the National Highway Traffic Safety Administration, launched a highly publicized yearlong statewide sobriety checkpoint program. ${ }^{172}$ Despite low arrest yields, the program was considered successful in reducing the number of drunk driving fatalities. ${ }^{173}$ There is no doubt that any rigorous, well-publicized anti-drunk driving campaign will raise the level of public awareness and increase the perceived risk of arrest. ${ }^{174}$ However, it is nearly impossible to determine the true extent of the program's deterrent effect. ${ }^{175}$ The most important inquiry should be: Are sobriety checkpoints superior to alternative methods to the extent that they justify circumventing traditional notions of privacy? As this Note concludes, the answer is no.

\section{B. Sobriety Checkpoint Effectiveness in Indiana}

Between 1994 and 2011, Indiana had a drunk driving fatality rate of twentyseven percent, which was lower than both the national average and the combined fatality rate of states allowing checkpoints. ${ }^{176}$ This does not provide significant support for those in favor of checkpoint programs. For example, Michigan, does not allow sobriety checkpoints yet it experienced a fatality rate of thirty percent during the same time period. ${ }^{177}$ Although this rate was higher than Indiana's, it was below the national average and equal to the combined fatality rate of states that allowed checkpoints. Furthermore, Michigan experienced 2.6 drunk driving fatalities per 100,000 citizens, ${ }^{178}$ whereas Indiana had 3.2 fatalities per 100,000 Hoosiers. ${ }^{179}$

Inconclusive statistical data regarding alcohol related crash fatalities is certainly a major hurdle in assessing the effectiveness of sobriety checkpoints. Moreover, courts have been forced to evaluate the success of such programs based largely on arrest rates and perceived deterrence. ${ }^{180}$ In assessing the effectiveness of the sobriety checkpoint in Gerschoffer, the Indiana Supreme Court sought to have its cake and eat it too. The court first looked at the

172. Greene, supra note 164 , at 3-4.

173. Id.

174. Id. at 4-5; see also RoBIN, supra note 5, at 115.

175. Greene, supra note 164 , at 4.

176. See NAT'L HighWAY TrAfFIC SAFETy AdMIN., supra note 166.

177. Id.

178. Michigan Drunk Driving \& Underage Drinking Statistics, ThE CENTURY CouncIL, http://www.centurycouncil.org/state-facts/michigan (last visited Jan. 20, 2014), archived at http://perma.cc/P6GL-GT77 (citations omitted).

179. Indiana Drunk Driving \& Underage Drinking Statistics, THE CENTURY CounCIL, http://www.centurycouncil.org/state-facts/indiana (last visited Jan. 21, 2014), archived at http://perma.cc/78R5-KZ8S (citations omitted).

180. See RoBIN, supra note 5, at 39. 
checkpoint's arrest rate to determine its effectiveness. ${ }^{181}$ If the rate was low, evidence of sufficient media publicity could be used to account for the low number of arrests. ${ }^{182}$ In the court's words, if sufficient evidence is shown, the court may "infer that the low apprehension rate was the effect of a successful media blitz." 183 "[A] modest arrest rate may simply reflect the fact that advance publicity scared those who would drink and drive off the roads." ${ }^{184}$ Thus, it seems that Indiana courts presume a checkpoint to be effective if it has been well publicized.

\section{ALTERNATIVE APPROACHES FOR INDIANA}

Aside from sobriety checkpoints, other commonly used anti-drunk driving tactics used by law enforcement officers include roving patrols and saturation patrols. ${ }^{185}$ Roving patrols are consistent with routine police patrols; officers patrol specific areas looking for signs of impaired driving. ${ }^{186}$ Saturation patrols are similar to roving patrols insofar that they also involve officers patrolling in specified areas looking for drunk drivers. ${ }^{187}$ However, they saturate these areas with more officers than would be used during a normal roving patrol. ${ }^{188}$ Furthermore, saturation patrols are somewhat similar to checkpoints as they target specific areas with a reputation for high incidences of drunk driving. ${ }^{189}$

The main difference between roving and saturation patrols and sobriety checkpoints is that patrols require reasonable suspicion, as is customary with any police stop; checkpoints require no such threshold. ${ }^{190}$ The Indiana Legislature should thwart the pressure to continue to allow sobriety checkpoints, and instead enact a law that will protect the privacy and dignity of fellow Hoosiers, while promoting sound police practices proven to remove dangerous drivers from Indiana's roadways.

\section{A. Roving and Saturation Patrols Versus Checkpoints}

This Note does not claim that sobriety checkpoints are altogether ineffective at combatting drunk driving. Rather, this Note describes the many shortcomings and dangers of police checkpoints, while identifying alternative approaches that are just as effective, if not more effective, at removing drunk drivers from the roads.

In a free society, law enforcement objectives should aim for an optimum

181. State v. Gerschoffer, 763 N.E.2d 960, 970 (Ind. 2002).

182. Id.

183. Id.

184. Id. (citations omitted).

185. Sobriety Checkpoints, supra note 19.

186. Id.

187. Id.

188. Id.

189. Greene, supra note 164 , at 3.

190. See id. at 2-3. 
balance between civil liberty and public safety. In Pimental, the Rhode Island Supreme Court stated that part of its basis for disallowing sobriety checkpoints was that reasonable and effective alternatives existed, thus the court could not justify carving out an exception to the privacy protections of the state constitution. ${ }^{191}$ Unfortunately, neither the United States Supreme Court nor the Indiana Supreme Court exercised such caution before upholding the practice of suspicionless stops. In Sitz, the Court discussed the possibility of effective alternatives and concluded that:

Experts in police science might disagree over which of several methods of apprehending drunken drivers is preferable as an ideal. But for purposes of Fourth Amendment analysis, the choice among such reasonable alternatives remains with the governmental officials who have a unique understanding of, and responsibility for, limited public resources, including a finite number of police officers. ${ }^{192}$

Perhaps the increased attention given to drunk driving prevention in the $1980 \mathrm{~s}$ and 1990s, ${ }^{193}$ as well as the immense public support, ${ }^{194}$ tipped the courts in favor of upholding sobriety checkpoints despite inconclusive data regarding their effectiveness and the existence of alternative enforcement tactics.

Some law enforcement agencies have made their own judgment regarding whether sobriety checkpoints are effective. Law enforcement officials in the Louisville metropolitan area, which encompasses north-central Kentucky and south-central Indiana, opted to use saturation patrols rather than sobriety checkpoints on New Year's Eve 2013. ${ }^{195}$ The New Year's holiday is a highstakes event for those charged with the task of reducing the number of drunk drivers, as it is among the most dangerous nights on the roadways. ${ }^{196}$ The head of the Louisville Metro Police Department's traffic division explained the rationale for using patrols rather than checkpoints:

When you're in a roadblock you have all your resources in that one location, and you're hoping the possible drunks are going to flow through. So instead of putting all our eggs in one basket so to speak, focusing in one location, I can send out [fourteen] to [sixteen] cars, and have [them] be in various locations around the city. Expanding the net so to speak. ${ }^{197}$

In the previous year, saturation patrols yielded nine drunk driving arrests, while

191. Pimental v. Dep't of Transp., 561 A.2d 1348, 1352 (R.I. 1989).

192. Mich. Dep't of State Police v. Sitz, 496 U.S. 444, 453-54 (1990).

193. See RoBIN, supra note 5, at 7-14.

194. See JASPER, supra note 10, at 21 (citations omitted).

195. Eric Flack, Police Prepare for Drunk Drivers on New Year's Eve, WAVE 3 NEWS (Dec. 2013), http:/www.wave3.com/story/5872713/police-prepare-for-drunk-drivers-on-new-years-eve, archived at http://perma.cc/7R4X-TSYJ.

196. Id.

197. Id. 
sobriety checkpoints produced no arrests. ${ }^{198}$ It appears that these law enforcement agencies judge the effectiveness of their DUI taskforces by their arrest rate rather than deterrent value.

Police in Tucson, Arizona made the same decision for New Year's Eve 2013, opting for saturation patrols rather than checkpoints. ${ }^{199}$ According to a law enforcement spokesperson, having units spread across an area patrolling was an effective deterrent. ${ }^{200}$ Sobriety checkpoints on the other hand serve more as an educational device; they are used to convey a police presence. ${ }^{201}$

In many ways, saturation patrols and sobriety checkpoints are quite similar. Both target drunk driving hot spots and do so with high visibility. ${ }^{202}$ Both saturation patrols and checkpoints are deployed during times when drunk driving is the most prevalent, such as major holidays and at night. ${ }^{203}$ As noted above, the crucial difference between saturation or roving patrols and checkpoints, is that saturation and roving patrols require reasonable suspicion before stopping a motorist. ${ }^{204}$ Officers on either roving or saturation patrols look for objective signs that a driver may be alcohol-impaired. ${ }^{205}$ Some common signs of impaired driving include: weaving, crossing the centerline, speeding or driving too slowly, slow response time at intersections, and improper signaling, among other atypical driving behaviors. ${ }^{206}$ Such suspicious behavior provides law enforcement officers with justifiable grounds to stop a motorist and further investigate whether the individual is intoxicated and a danger to the driving public.

Both the Court in Sitz and the court in Gerschoffer correctly concluded in their analyses that drunk driving is a major problem and that the government has a significant interest, both economically and socially, in combatting this problem. ${ }^{207}$ However, the courts presumably failed to consider alternative enforcement methods, which would have lessened the necessity for upholding the use of checkpoints. ${ }^{208}$ The Court in Sitz only mentioned roving patrols in an attempt to bolster the position of checkpoints, claiming that roving patrols generated more fear in motorists than did stops at police checkpoints. ${ }^{209}$ Neither

198. Id.

199. Bud Foster, DUI Checkpoints vs Saturation Patrols, TuCSON NEws Now (Dec. 31, 2013, 7:29 PM), http://www.tucsonnewsnow.com/story/24339053/dui-checkpoint-vs-saturation-patrols, archived at http://perma.cc/PU9F-QS9T.

200. Id.

201. $I d$.

202. See Greene, supra note 164 , at 2-3.

203. See id.

204. See id. at 3.

205. Id.; Sobriety Checkpoints, supra note 19.

206. RoBIN, supra note 5, at 21.

207. Mich. Dept. of State Police v. Sitz, 496 U.S. 444, 451 (1990); State v. Gerschoffer, 763 N.E.2d 960, 966 (Ind. 2002).

208. See Sitz, 496 U.S. at 453-54 (deferring to politically accountable officials with greater law enforcement expertise).

209. Id. at 452-53. 
the Court in Sitz nor the court in Gerschoffer provided a sound basis for permitting a departure from traditional law enforcement tactics, which require reasonable suspicion to conduct an investigatory stop. Instead, the courts chose to cast aside long-standing privacy protections and concerns, in favor of treating all motorists as suspects under the veil of public safety. ${ }^{210}$

\section{B. Maximizing Enforcement and Deterrent Value}

Despite the shortcomings and dangers of sobriety checkpoints and the controversy surrounding their use, law enforcement officers and policy makers can borrow ideas from sobriety checkpoint programs to make less intrusive tactics more effective. The most important factors for deterring drunk driving are publicity, public awareness, and creating the perception that individuals driving drunk will likely be caught.

Studies of drunk driving deterrence have shown that the short-term success of visible and publicized initiatives dwindle over the long-term. ${ }^{211}$ In the case of sobriety checkpoints, where advanced notice is given and law enforcement is anchored in a fixed location, motorists simply learn to avoid the checkpoint, thus the fear and probability of apprehension subsides. ${ }^{212}$ This is where saturation patrols provide a tactical advantage; since a drunk driver cannot easily avoid a patrol, his or her fear of apprehension, both real and perceived, is higher. ${ }^{213}$ By casting a wide net and targeting only those vehicles that show signs of impaired driving, law enforcement officers allocate their time and efforts toward removing active threats from the roadways, while remaining true to traditional reasonable suspicion standards. ${ }^{214}$

The general deterrence created by sobriety checkpoints can be most attributed to their high visibility and the media attention they attract. ${ }^{215}$ By working with media outlets to increase public awareness, the deterrent effect of saturation patrols can be increased. The higher arrest yields produced by saturation patrols gives more teeth to law enforcement efforts. ${ }^{216}$ Motorists observing police patrolling the roadways, seeing other individuals stopped on the roadside, and hearing news reports about the number of drunk driving arrests will increase the perception that they too would be arrested if driving while intoxicated. ${ }^{217}$ Publicity given to checkpoint programs does indicate to the public that DUI enforcement is a priority, yet it also provides potential drunk drivers

210. See id.

211. RoBIN, supra note 5, at 115.

212. See id.

213. See Greene, supra note 164, at 5 .

214. See Pimental v. Dep't of Transp., 561 A.2d 1348, 1352 (R.I. 1989).

215. Greene, supra note 164 , at 2-3.

216. Id. at 5 ("It is proven that saturation efforts will bring more DUI arrests than sobriety checkpoints.").

217. See RoBIN, supra note 5, at 116-17 (Figure 13.2 discusses the success of a prolonged, highly-publicized saturation patrol program in decreasing accident frequency). 
with the information necessary to avoid encountering the stop. ${ }^{218}$ Wellpublicized saturation patrols indicate the enhanced efforts of law enforcement while maintaining the fear factor necessary to scare drunk drivers off of the roads.

\section{PRoposed Indiana STAtUTE}

Keeping in mind the aforementioned considerations, an Indiana statute banning sobriety checkpoints should read as follows: ${ }^{219}$

1. Definitions:

a. "Traffic Checkpoint" means a roadblock at which law enforcement officers stop motorists, absent individualized suspicion, to check for violations of state law.

b. "Commercial Motor Vehicle" is a motor vehicle that must be operated by an individual possessing a commercial driver's license under IC 9-246.

c. "Sobriety Checkpoint" means a Traffic Checkpoint established to enforce state laws for impaired driving.

2. Law enforcement agencies of this state may conduct a traffic stop only upon reasonable suspicion of a violation of state law by a motorist.

3. Law enforcement agencies in this state shall not conduct Traffic Checkpoints for the purpose of enforcing the criminal laws of this state.

4. Exceptions to Sections (2) and (3):

a. Law enforcement agencies may conduct checkpoints to enforce state laws and safety regulations on Commercial Motor Vehicles.

b. Law enforcement agencies may conduct emergency traffic checkpoints in response to specific and imminent threats to the health, safety, and welfare of the public.

c. Subsection (b) does not permit sobriety checkpoints.

\section{CONCLUSION}

Combatting drunk driving is an important and laudable public policy objective. National campaigns together with state and local law enforcement efforts have undoubtedly reduced the negative impact of drunk driving on communities, families, and individuals. However, the war against drunk driving is ultimately unwinnable; in a free society like our own, no government policy will ever completely rid the nation's highways and byways of alcohol-impaired drivers. We can only hope to limit the damage caused by drunk drivers while mitigating the intrusion on civil liberties.

Large public support coupled with deferential judges at both the federal and state level allowed law enforcement officials to circumvent protections against suspicionless and unreasonable searches and seizures. Challenges to sobriety

218. Greene, supra note 164 , at 2-3.

219. See Iowa Code $\S 321$ K.1 (2013); see also N.H. ReV. Stat. AnN. § 265:1-a (2013) (These statutes served as a guide for drafting this proposed statute). 
checkpoints displayed a unique form of federalism in which some state constitutions, as interpreted by state courts, afforded their citizens stricter protections of their civil liberties than the United States Constitution. This allows an examination of the propriety of court rulings that have concluded sobriety checkpoints are reasonable seizures. The states serve as fifty laboratories of democracy, providing comparative data by which policy makers can assess the effectiveness of different drunk driving enforcement methods.

The State of Indiana should prohibit the use of police checkpoints in its efforts to combat drunk driving. However, it is highly unlikely the Indiana Supreme Court would reverse course due to the precedent established in Gerschoffer, the United States Supreme Court's holding in Sitz, and the fact that courts and legislatures in thirty-seven other states permit sobriety checkpoints. Therefore, this issue is in the hands of the Indiana General Assembly.

Effective alternatives, such as roving patrols and saturation patrols, based on individualized suspicion and probable cause, should be deployed instead of sobriety checkpoints. As supporters, law enforcement officials, and judges alike have conceded, sobriety checkpoints yield fewer arrests for alcohol-impaired driving than do roving patrols. ${ }^{220}$ Thus, the success of sobriety checkpoints is primarily gauged on their deterrent effect. Moreover, the spectacle of a sobriety checkpoint signals to the community that drunk driving prevention is a priority. ${ }^{221}$ In addition to higher arrest rates, roving patrols and saturation patrols also have a deterrent function, which can be enhanced with greater publicity and visibility.

With roughly thirty percent of vehicular crash fatalities involving alcohol impairment, combating drunk driving is an important priority nationwide. ${ }^{222}$ However, we should be cautious when well-intended policy proposals begin to erode our civil liberties. Too often we ignore the unintended consequences of our overzealous pursuit of noble goals. The Indiana General Assembly should look past public ardor and prohibit police checkpoints and adopt alternative measures. More importantly, Indiana citizens must demand enforcement procedures that effectively combat the problem, while mitigating the interference with law-abiding citizens' rights. Public support is the biggest hurdle for civil libertarians in the fight over sobriety checkpoints, but it is a battle worth fighting.

220. See, e.g., State v. Gerschoffer, 763 N.E.2d 960, 970 (Ind. 2002) (citations omitted).

221. See Foster, supra note 199 (noting that checkpoints are deployed as an educational device).

222. NAT'L HighWAy TRAFFIC SAFETy AdMIN., supra note 166. 
